Journal of Humanities, Social and Management Sciences (JHSMS)

https://doi.org/10.47264/idea.jhsms/1.1.1

Vol. 1, No. 1 (January-December 2020), 01-16

https:// www.ideapublishers.org/index.php/jhsms

Research Article

\title{
Cellular Phone Text Messaging Patterns \& Teenagers of Southern Punjab: A Using and Gratification Analysis
}

\author{
Shahzad Ali, Faryal Sohail, \& Muhammad Makkey Bhutta* \\ Department of Communication Studies Bahauddin Zakariya University, Multan, Pakistan. \\ * Corresponding Author Email: makkey_k@hotmail.com
}

\begin{abstract}
The modifications in mobile phone technology have transformed the trends of people in Pakistan, particularly teenagers. The feature of text messaging is being excessively used for interpersonal communication among teenagers. The present study focuses on the text messaging consumption patterns and the behavioral trends among the teenagers of southern Punjab, Pakistan in the light of uses and gratification approach. Survey research designed was adopted with structured questionnaires. The sample included 627 teenagers studying in various institutions of Multan City. The results of this research revealed that teenagers frequently use text messaging to communicate with others as it is a convenient way of communication. Respondents also showed a tendency of answering the messages from unknown people. Specifically, teenage boys have more tendency of replying to strangers and texting while sitting in family gatherings as compared to girls. Conclusively, it was revealed in this study that text messaging is a distractive activity with the capacity of giving opportunity to individuals to gratify the specific desires. In this rigid and socially segregated society of Pakistan text messaging is the most popular mean of communication without denying its pros and cons.
\end{abstract}

Keywords: Text Messaging, Teenagers, Texting trends, Southern Punjab, Mobile Phones.

How to Cite:

Ali, S., Sohail, F. \& Bhutta, M. M. (2020). Cellular Phone Text Messaging Patterns \& Teenagers of Southern Punjab: A Using and Gratification Analysis. Journal of Humanities, Social and Management Sciences (JHSMS), 1(1), 01-16. https://doi.org/10.47264/idea.jhsms/1.1.1

Publisher's Note:

IDEA PUBLISHERS (IDEA Journals Group) stands neutral regarding jurisdictional claims in the published maps and institutional affiliations.

\section{Copyright:}

(C) 2020 The Author(s), published by IDEA PUBLISHERS (IDEA Journals Group)

This is an Open Access article published under the Creative Commons Attribution-NonCommercial 4.0 International License (http://creativecommons.org/licenses/by-nc/4.0/) 


\section{Introduction}

Mobile phones have revolutionized the patterns of communication. It has influenced the social life of people and the modes of their interaction with others. Cell phones have become a legit part of every individual's life. The last decade has seen a tremendous evolution in forms of communication, particularly through mobile phones. Text messaging has become a most adopted phenomenon for interpersonal communication. According to Grinter \& Eldrige (2001) text messaging is a regularly used mode for interpersonal communication due to its affordability and accessibility. Therefore, youngsters use text messaging more and it is taking the place of face-to-face communication because of its convenience. Likewise, Individuals do texting while driving also (Lee \& Perry, 2007). Text messaging is the exchange of brief texts between cell phones and this form of communication has many features. For example, there is no standardized rule of texting or the use of correct spellings is not mandatory. Therefore, the rules of grammar and other communication conventions are disregarded while text messaging. This unconventional form of communication offers easy and quick way of response. Similarly, text messaging is an economical, time and space saving process (Lieke-Verheijen, 2013).

There has been a quick increase in text messaging as there has been a rise of number of mobile phones subscribers more than 7 billion users, globally and more in developing countries (Kazi et al., 2018). In the last decade, Pakistan has also seen a radical increase in the subscribers of mobile phone users. PTA reports that currently there are 152.16 Million mobile phone subscribers in Pakistan. Therefore, teledensity stands at 74\% in 2018.

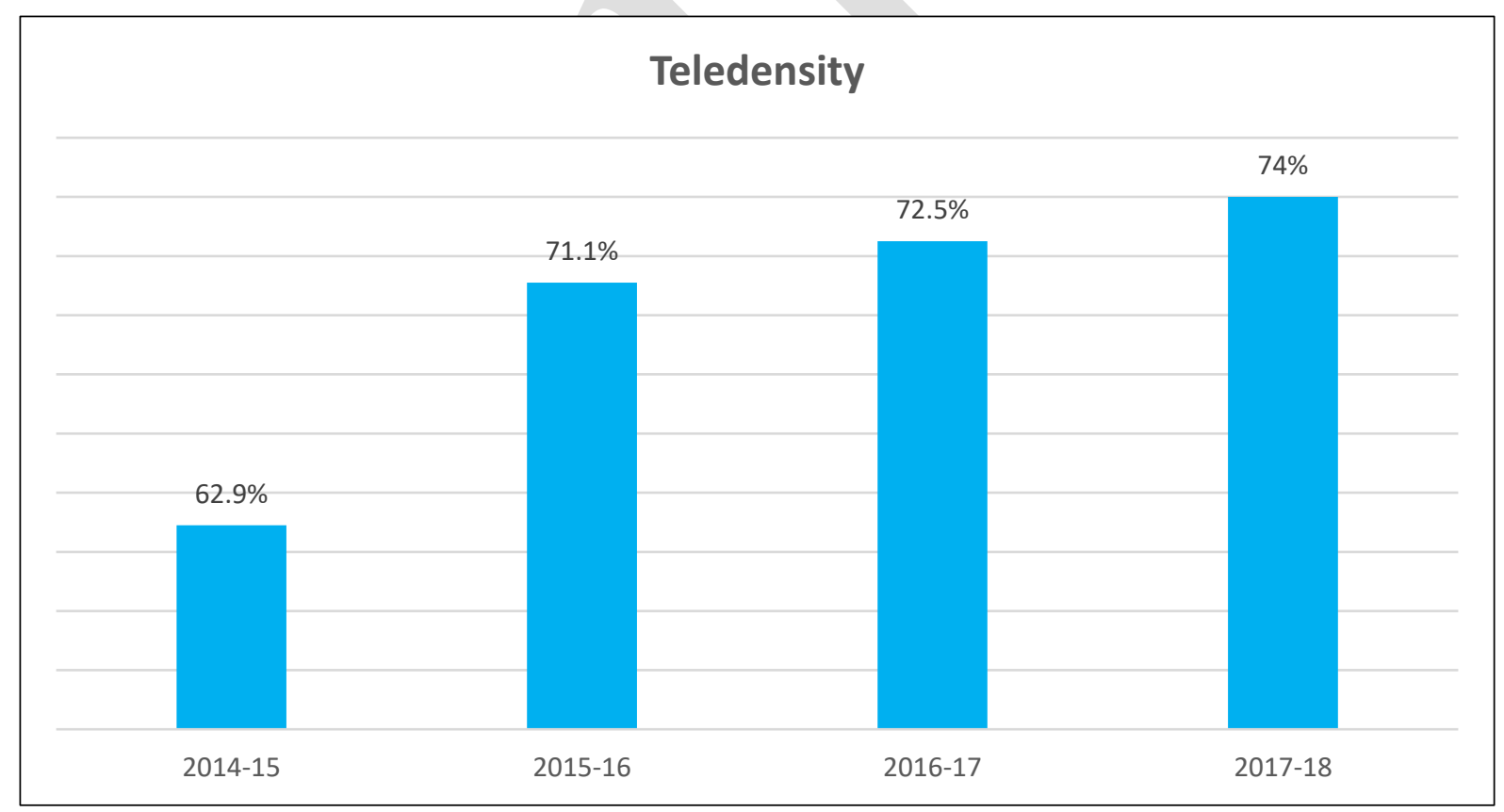

Figure 1: Tele density Economic Survey 2017-18 by ministry of Finance, Pakistan

As of June 2018, the mobile subscribers have reached to 10.5 million. According to PTA there are 4 major cellular network companies working in Pakistan which are Telenor, Zong, jazz and ufone. PTA revealed that Ufone consumers have been reached up to 21.1 million in October 2018. Telenor company subscribers have been extended to 43.15 million and Zong has 31.7 million number of subscribers. Jazz has the highest number of subscribers of 56.17 million (www.telecoalert.com). 
Table-1: Cellular network subscribers in Pakistan (2017-2018)

\begin{tabular}{lll}
\hline Cellular company & October 2018 & 2017 \\
\hline Ufone & 21.1 million & 18.478 million \\
Zong & 31.7 million & 27.496 million \\
Telenor & 43.15 million & 39.586 million \\
Jazz & 56.17 million & 51.534 million \\
\hline
\end{tabular}

Source: Pakistan telecommunication authority, 2018

According to the statistics of PTA the cellular market share as of October 2018 of jazz has been $36.92 \%$. Telenor has been able to grab the market share of $28.37 \%$. Likewise, Zong has the market share of $20.84 \%$ and Ufone has the lowest market share of $13.87 \%$ as shown in figure 1. These figures of market share of cellular network give the indication of highest market share holder i.e., Jazz. Its highest grossing of market share is because of its acquisition with Warid telecom. After Jazz, the runner up market holder is Telenor. Zong stands at third place and Ufone has the lowest share in this market of cellular subscription.

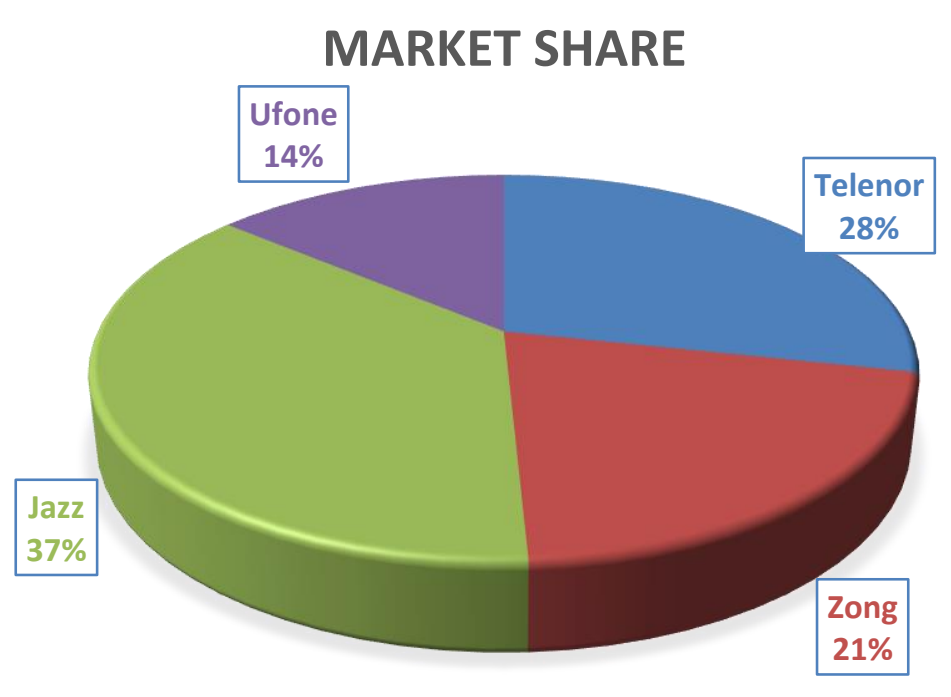

Figure 2: Market share of cellular networks in Pakistan

According to Russell (2010) text messaging language affects the students because "texting" make them use the abbreviations and slangs which impact their daily use of language. Text messaging blur the lines between slangs, abbreviations and correct English. Conferring to the results of a global survey by Nokia in 2002, on text messaging it was discovered that the phenomenon of text messaging is addictive. Additionally, it was also cleared out text messaging is the most used service on mobile phone with the need of quick response to stay in touch. Youngsters prefer text messaging due the empowerment of control, privacy and convenience it gives them while communicating. However, individuals believe that face to face communication is beneficial yet they prefer text messaging more for interpersonal communication (Massimini \& Peterson, 2009). Text messaging services come with various benefits. According to Horstmanshof \& Power (2005) people believe in text messaging because it makes possible to create an ambiance of privacy and coziness while talking with others which makes this act more interesting and consistent. Similarly, the intensive use of text messaging 
is directly influence an individual's psychological and physical life. It may cause the social isolation, depression, sleep disorders, body discomfort and many other physical issues (Linn \& Peper, 2009; Massimini \& Peterson, 2009; Horstmanshof \& Power, 2005). Thurlow and Brown (2003) claims that young generation is highly dependent on text messages and now it has become a culture.

Subsequently, Text messaging phenomenon has user friendly construction. It gives user the opportunity to think and construct the messages. It allows sender and receiver to build a well composed conversational ambiance. This discourse method of text messaging resembles to online chatting because of its immediate and uninterrupted response system. There are various dimensions of text messaging and its impact on individuals. As described by Haig (2002) 90\% of teenagers prefer to communicate through text messages rather than direct calls, which may impact on their behavior patterns. Consequently, it can be said that the use of text messaging is on increase and it is affecting the behavioral patterns because individuals prefer a text message when they want to avoid a face-to-face conversation. This mode of conversation is expressionless because of lack of gestures like face expressions, tone of voice etc. The verbal communication patterns are being surpassed by text messaging. There are insignificant studies on this topic therefore; it would be interesting to know the texting behavior patterns of teenagers and their impacts on them.

\section{Literature Review}

Text messaging is one of the frequently used communication form. In a survey, the psychological and social effects of text messaging were explored and it was found out that text messages help to initiate and develop new relationships. It was also reported that frequent use of text messages affected their bond with their families and participants were inclined towards text messaging instead of real or face to face meetings (Reid \& Reid, 2004). Therefore, text messaging evidently offers a convenient way of communication. This form of interpersonal communication is assumingly used to present an idealized persona to others. Individuals feel more comfortable and intimate while communicating through text messages and tend to use text messages more for developing relationships than using it for some purposeful task (Thurlow \& Brown, 2003; Ling \& Yttri, 2002). Similarly, Leung (2001) claimed that text messages are used for gratification. Individuals do text messaging for recreation and amusing themselves. In short, text messaging is the source of distraction.

Due to the advent of new technologies and upgraded mobile phone features people have become more dependent on these gadgets for interpersonal communication. This phenomenon has led to the addiction of mobile phones and the feature of text messaging. Henderson et al. (2002) stated that messaging allows semi private communication with other individuals with the opportunity to get involved covertly in social groups. Srivastava (2005) investigated the usage of mobile phones by students during school hours and it was revealed that they use their mobiles phones during lectures and especially for text messaging others. This kind of behavior shows the urge to stay connected and make sure their presence in other people's lives (Warner, 2003).

Mobile phones have practically become a part of everyone's social life and their daily practices. It was found out by Horst and Miller (2005) that Jamaicans who are culturally religious and submissive take the discovery of mobile phones as a gift from God. Therefore, it wouldn't be 
wrong to say that mobile phones have become the part of people's life. Lenhart (2009) states that frequency of use of text messages have been increased in teens regardless of the ownership mobile phones. He further explained that in daily routine the communication through mobile phone is overpowering the other modes of communication. Almost 2 in 5 teenagers do text messaging on daily basis. According to the results of his study $38 \%$ of teenagers are involved in text messaging activity, $36 \%$ use call service, $32 \%$ prefer face to face communication and rest of the teenagers use internet for communication like social media and emails. Similarly, the study of Lee and Perry (2007) revealed that while text messaging individuals tend to lose focus of their surroundings and get immersed in their mobile phones. This is how it becomes an addictive and habitual activity because of over consumption of text messaging service.

The extensive use of mobile phones and text messaging become a reason for short attention spans in teenagers. Stothart et al. (2015) stated in their experiment that mobile phones have the power to interfere the "focused attention" of an individual even though he tends to ignore the interruption of any notification received on a mobile phone. That is how individuals get anxious to check their mobile phone even during their most important work. Similarly, in another study it was claimed that Mobile phones cause the short attention span in people. The features on mobile phones drive the individual to lose its focus abruptly and lose the sustained attention. This leads to the phenomenon of "Mobile phone addiction" (Lee et al., 2015).

The use of mobile phones affects the psychological state of the person. Also the cultural life of people gets affected by the patterns of technology. Hofvenschiold (2003) explained that obvious changes in the attitudes of people can be seen due to use of mobile phones. In an another comparative study of teens of japans and USA it was concluded that $69.53 \%$ of Japanese teenagers chose to do text messaging and $35.5 \%$ of USA teenagers picked the games on mobile phones to play.

Lemola et al. (2014) conducted a survey to explore the relation between mobile phone usage and its effects on cognitive abilities and mood. It was recorded that sleep interruptions with some depressive symptoms were found with the excessive usage of mobile phones. Additionally, Van den Bulck (2003) further elucidates that text messaging behaviour causes disturbances in routine work. It makes teenagers to sleep late and feel restless if replies are late. This is how the interruptions in sleep patterns are observed. A study conducted in Korea of 595 students exposed that with the frequent use of mobile phones causes' social anxiety, lack of confidence in face-to-face communication and depression. In short, it causes strong psychological affects (Ha et al., 2008).

According to Sutherland (2002) text messaging effects the usage of language. Due to the no apparent restrictions on the usage of correct grammar and complete words, text messaging behaviour gives rise to the adaptation of sloppy and naïve use of words while texting. This behaviour reduces the use of authentic language during interpersonal communication. This phenomenon of not paying attention to the correct language leads to the habit of using poor spelling and unnecessary abbreviations.

Additionally, use of mobile phones and excessive use of text messaging results in educational and health hazards with the possibility of involvement in unhealthy activities like fights, alcoholism etc. In a study Individuals tend to prefer text messaging and $85 \%$ of youngsters chose text messaging as compared to other modes of interpersonal communication (Matthews, 
2004). The consumption patterns of mobile phones of males and females are different which define their relationship with this gadget. Female and male adopt the usage of mobile phones differently. Females get addictive to mobile phones and male style of using mobile phones is regarded as a technology interest (Wilska, 2003).

The new era of ICTS and new media technology is making the society more habitual of using mobile phones. Fortunati (2002) says that this gadget is altering our trends of communication and affecting the society at large. Hence, Mobile phones have become a constant need. In the view of most of the researches it can't be overlooked that mobile phones and text messaging have the capacity to affect individuals. The researchers on the use of mobile phones and its effects on the users are often limited because of increasing landscape of technology with diverse changes in the society and behavioural trends. Regardless of such restrictions, the fact that mobile phones have diverse impact on individuals especially teenagers, can't be denied.

\section{Statement of the Problem}

In this following study, researcher tends to assess the text messaging consumption patterns and the behavioural trends regarding this activity among the teenagers of southern Punjab, Pakistan. Study is conducted in the light of uses and gratification approach because there are certain drives behind text messaging services of mobile phone. The $21^{\text {st }}$ century has witnessed advancements in technology and created new aspects for interaction between humans. Similarly, text messaging is one of the most used way of interpersonal communication and individuals may achieve certain gratifications while texting. Text messaging related habits and consequences has become inescapable to investigate because of their visible impacts on individuals. Therefore, this study focused on the following categories defined by Katz, Gurevitch (1973).

a. Cognitive needs: A desire to know and understand with the love for exploration.

b. Affective needs: It involves achieving emotional connection and pleasure out of something.

c. Personal integrative/identity: A need to solidify personal identity or traits for social recognition.

d. Social integrative/interaction: The need for affiliation or connection with the social world.

e. Tension release needs/escapism: The need to escape from everyday pressures through certain distractions.

\section{Hypotheses}

H1: A large number of the teenagers would prefer text messaging on account of parsimony/economical nature.

$\mathrm{H} 2$ : Most of the teenagers would be responsive to text messages from strangers for their affective needs

H3: Most of the teenager's would-be more likely to forward text messages to solidify personal identity.

H4: Most of the teenager's would be more likely to share text messages for escapism and sexual gratification

H5: Most of the teenagers would agree that the habit of messaging would affect their studies. 
H6: Most of the respondents are likely to send less messages while multitasking and presence of family.

H7: Majority of the teenagers would adopt the style of contraction while drafting messages. (Results reported here are significant at the $p<.05$ level.)

\section{Research Methodology}

In order to explore the trends of text messaging among teenagers and to look into the gratifications they get from texting, survey technique was applied. The sample consists of 627 respondents, with $50.5 \%$ males and $49.5 \%$ of the females belonging to leading educational institutions of Multan city, Punjab. Convenient sampling technique was applied. As the respondents are teenagers, the education level is Matric and intermediate. 57.8\% respondents were having intermediate and $42.2 \%$ were the students of Matriculation. While, $85.5 \%$ of them own single set of mobile phone, $14.5 \%$ have two mobile phones and only $5 \%$ carried three cell phones. The rate of text messages exchange was also asked from the respondents, $26.4 \%$ of them sent 10-50 messages per day and 32.3\% respondents send less than 10 text messages a day. Whereas, $12.2 \%$ respondents send more than 100 messages and $13.8 \%$ send more than 200 messages a day. The interest in SMS packages was also find out in this study, $77.6 \%$ were interested and subscribers of SMS packages. On the other hand, 22.4\% respondents don't subscribe for SMS packages.

Table-2: Motives behind sending text messages

\begin{tabular}{llll}
\hline Reasons & Boys & Girls & Total \\
\hline Convenient way to communicate & $140(44)$ & $168(54)$ & $308(49)$ \\
Economical way to communicate & $63(20)$ & $64(20)$ & $127(20)$ \\
Due to privacy factor & $46(15)$ & $27(9)$ & $73(12)$ \\
To avoid direct interaction & $32(10)$ & $39(12)$ & $71(11)$ \\
To make new friends & $36(11)$ & $12(5)$ & $48(8)$ \\
Total & 317 & 310 & 627 \\
\hline
\end{tabular}

The above table 2 indicates, $49 \%$ of teenagers consider that text messaging is the convenient way to communicate and a quick service to get in touch. However, $20 \%$ of teenagers believe that it's an economical way of communication probably due to SMS packages, which is why they believe in text messaging. $12 \%$ of teenagers use this text messaging service because of the sense of privacy it gives. $11 \%$ of the respondents do texting to avoid face to face communication and find it easy way to talk to someone without any direct interaction. $8 \%$ of the teenagers are of the view that they send messages to make new friends.

Table-3: Texting for affective needs

\begin{tabular}{llll}
\hline Response to messages from strangers & Boys & Girls & Total \\
\hline Yes & $143(46)$ & $27(9)$ & $170(28)$ \\
No & $174(54)$ & $283(91)$ & $457(72)$ \\
Total & 317 & 310 & 627 \\
\hline
\end{tabular}

Chi Square Value $=21.50$

P.value $=0.000$

The results in the above table 3 show that most of the respondents are restricted about answering the messages they receive from unknown numbers. 54\% of male and $91 \%$ of female teenagers expressed that they don't answer to messages from unknown numbers. While, $46 \%$ of males do reply to unknown people on text messages because they think it's harmless. Only 
$9 \%$ of girls respond to text messages from unknown. The $\mathrm{p}$ value is 0.000 , showing that the likelihood of giving response to SMS from unfamiliar person would be greater amongst teenage boys as compared to teenage girls for pleasure.

Table-4: Solidification of personal identity through text messages

\begin{tabular}{llll}
\hline Sharing messages to gain credibility & Boys & Girls & Total \\
\hline Yes & $187(59)$ & $177(57)$ & $364(59)$ \\
No & $130(41)$ & $133(43)$ & $263(41)$ \\
Total & 317 & 310 & 627 \\
\hline
\end{tabular}

According to the results in table 4,59\% of the respondents agreed that they send text messages for the sake of gaining credible status among others and reassuring the personal integrity. On the other hand, $41 \%$ teenagers responded that they don't need self-recognition through text messages.

Table-5: Text messaging for the sake of escapism and sexual gratification

\begin{tabular}{lllll}
\hline & & Boys & Girls & Total \\
\hline Escapism & Yes & $161(50.8)$ & $167(53.8)$ & $328(52.3)$ \\
& No & $156(49.2)$ & $143(46.2)$ & $299(47.7)$ \\
Total & & 317 & 310 & 627 \\
Sexual Gratification & Yes & $130(41)$ & $41(13.2)$ & $171(27.2)$ \\
& No & $187(59)$ & $269(86.8)$ & $456(72.7)$ \\
Total & & 317 & 310 & 627 \\
\hline
\end{tabular}

Chi square value $=16.08$

P.value $=0.000$

Findings of table 5 show that teenagers gratify their need of escapism and a relief from everyday stress through text messaging. $52.3 \%$ of the teenagers revealed that they send messages to release tensions and feel distracted from daily stress. Although $47.7 \%$ of the respondents said they don't message others to feel distracted from daily pressures. It was also observed that girls were slightly more involved in text messaging for the sake of tension release phenomenon. Findings of above table interpret that sharing of text messages based on sexual content is greater among boys rather than girls. The Chi square test was conducted. The value $\chi 2=16.08$ and $p=0.000$ show the significance results of sharing of messages of sexual content. According to the ratio, $41 \%$ of the boys do receive messages based on sexual content and $13.2 \%$ of girls also receive these kinds of messages.

Table-6: Text messaging effects on studies

\begin{tabular}{llll}
\hline Response & Boys & Girls & Total \\
\hline Yes & $125(40)$ & $237(77)$ & $362(58)$ \\
No & $192(60)$ & $73(23)$ & $265(42)$ \\
Total & 317 & 310 & 627 \\
\hline
\end{tabular}

The results in table 6 clearly indicate that $58 \%$ of the teenagers believe that the practice of text messaging effect their studies. This routine of texting during studying makes them lose the focus and it directly effects on their progress in study. This habit of texting during the study creates a short attention span in teenagers which make them lose the concentration easily. Hence, it can be said that texting do bring negative consequences on teenagers regarding their studies. 
Table-7: Text messaging while multitasking and presence of family

\begin{tabular}{lllll}
\hline Response & & Boys & Girls & Total \\
\hline Texting While reading & Yes & $95(30)$ & $80(26)$ & $175(28)$ \\
& No & $220(70)$ & $230(74)$ & $452(72)$ \\
Texting While watching TV & & 317 & 310 & 627 \\
& Yes & $177(56)$ & $233(76)$ & $410(66)$ \\
& No & $140(44)$ & $77(24)$ & $217(34)$ \\
Texting while using internet & & 317 & 310 & 627 \\
& Yes & $110(35)$ & $73(24)$ & $183(30)$ \\
In presence of family & No & $207(65)$ & $237(76)$ & $444(70)$ \\
& & 317 & 310 & 627 \\
Total & Yes & $187(59)$ & $98(32)$ & $285(46)$ \\
& No & $130(41)$ & $212(68)$ & $342(54)$ \\
\hline
\end{tabular}

Table 7 reveals that teenagers prefer not to text when they are reading something. According to the results it is indicated that $72 \%$ of teenagers don't text when they are reading books or newspapers. They prefer focusing on reading and refrain from text messages. Most of the respondents send more messages while watching TV. Results indicate that $66 \%$ of teenagers send messages while watching TV. This table also reveals that teenagers don't send text messages when they are suffering the internet. Internet keep teenagers busy so the rate of text messaging is less when using internet. Teenagers get more occupied when they do multitasking on the internet; therefore the activity of text messaging is neglected. The ratio of sending messages among teenage girls in the presence of their family members is lesser than teenage boys also $54 \%$ of the respondents refrain from texting when sitting among family members.

Table-8: Number of text messages per day among teenagers

\begin{tabular}{lllc}
\hline Messaging /day & Boys & Girls & Total \\
\hline Less than 10 & $67(21.1)$ & $136(43.8)$ & $203(33)$ \\
$10-50$ & $91(28.7)$ & $75(24.1)$ & $166(27)$ \\
More than 50 & $55(17.3)$ & $39(12.5)$ & $94(15)$ \\
More than 100 & $47(14.8)$ & $30(9.6)$ & $77(11)$ \\
More than 200 & $57(17.9)$ & $30(9.6)$ & $87(14)$ \\
Total & 317 & 310 & 627 \\
\hline Chi Square Value $=19.42$ & & & P.Value $=0.025$
\end{tabular}

Table 8 illustrates that teenage boys comparatively send more text messages than girls. Data reveals that $9.6 \%$ of the girls send more than 100 texts per day. However, $14.8 \%$ of the boys send more than 100 text message/day. Hence, it is clear that boys send more messages in a day as compared to girls. Results also show that boys send more than 10 messages a day while majority of girls send messages less than 50 in one day. The value $\chi 2=19.42$ and $p=0.025$ shows that hypothesis is statistically significant.

Table-9: Mode of Text messages adopted by teenagers

\begin{tabular}{llll}
\hline Mode of texting & Boys & Girls & Total \\
\hline Complete Text & $120(38)$ & $93(30)$ & $213(34)$ \\
Use of contraction & $197(62)$ & $217(70)$ & $414(66)$ \\
Total & 317 & 310 & 627 \\
\hline
\end{tabular}


Results in the table 9 demonstrate that majority of the teenagers adopt the style of contraction while drafting a text message. This trend of text messaging is shown in the form of contractions in table below. This mode of texting is popular because it saves time. It's rather easy to type texts in short forms because almost all the teenagers use this type of texting style. According to the data, teenage girls use contraction style of text messages more than boys.

\section{Discussion}

The purpose of this study was to investigate the text messaging behaviour of the teenagers of the Southern Punjab. The sample comprised of 317 and 310 boys and girls belonging to various public and private educational institutes of Multan city. This study primarily aimed to explore general consumption pattern of Text messaging among teenagers in this part of PunjabPakistan which is not considered as metropolitan in true sense in comparison with other major cities of Pakistan.

The findings of this study specified that quite a good number of individuals send more than 100 messages a day and interestingly maximum number of teenagers are the subscribers of daily SMS packages to gratify their cognitive and affective desires. Hence, the cheaper SMS packages and other motives make it easy to retain this activity of text messaging. It was explored that the most of the teenagers would do more text messaging on account of convenience. They consider text messaging as the easiest and appropriate way to communicate that is why they prefer this mode of communication. Interestingly, it was also found that most of the teenagers don't mind in replying the texts they get from unknown numbers. Additionally, the ratio of sending response to SMS from unfamiliar person was found to be greater among teenage boys as compared to teenage girls. It was also explored that teenagers send text messages to solidify their personal identity through sharing messages and reassuring their credibility among others. Therefore, teenagers have this tendency of gratifying their need of personal integrity through text messages. This study also revealed that teenagers use text messaging as a source of escapism from daily pressures. Most of the respondents agreed to this assumption that they satisfy their need of stress release with the help of text messaging activity because they get distracted from all the tensions when they text others.

This mode of communication is used in various ways for gratification purpose. The sharing of sexual content messages was found among the teenagers and the ratio of receiving of sexual content-based SMS/MMS was more likely to be greater among teenage boys. Results also indicated that teenage boys forward more sexual messages as compared to teenage girls. Apart from this, most of the teenagers (Both girls and boys) respondent believed that habit of messaging would affect their studies. And the ratio of sending messages while using internet is less, which means when teenagers surf on internet they get occupied with the cyber space and other activities on internet so they forget about text messaging. The text messaging behaviour was also explored in presence of family, and results showed that teenage boys tend to send messages sitting in gatherings while girls feels shy about texting when sitting around people. Most of the respondents responded that they send less messages while reading books or newspapers and send more messages while watching TV. So, that means most of the teenagers prefer to focus on reading more than texting. Furthermore, text messaging behaviour among teenage boys for making new friends would be higher than teenage girl was significantly proved true. Likewise, predicted that most of the respondents would use text messaging to keep in touch with friends. This was proved true. Lately, a new trend of typing 
text messaging has been adopted by teenagers, style of contraction. This way of typing text messages in short forms saves the times and also it has become a norm of text messaging because it is now adopted by everyone. Majority of the teenagers adopt the style of contraction while drafting messages.

The cell phone technology has created a remarkable impact lives and social behaviours. Majority of teenagers irrespective of gender possessed cell phones with more than one SIM (A small card inside mobile phone) in operation. However, prices, stylish expensive and multidiversity in more sophisticated features of cell phone's possession-these features were correlated and explored with affordability of the families of teenagers, as our findings endorsed the study of Wilska (2003). Moreover, as it was revealed by Weilenmann and Larsson (2001) that teenagers used cell phones as a tool of social interactions, by and large similar results were found in the context of Pakistani teenagers.

Pakistani society entails a rigid environment and discrimination based on gender is an obvious phenomenon in this society. Here interaction of any kind with opposite sexes frowned upon and discouraged apart from for any blood relation. This creates an atmosphere of serious restrictions and limitations for youngsters as per moral codes. Due to these social and religious constraints, text messaging has become a popular mode for communication with privacy factor.

As the results categorically unveil those teenagers have different purposes of text messaging and motives of mobile phone texting. A large number of teens revealed the tendency of using text messaging services to befriend the opposite sex, especially unknown people. This practice help individuals in concealing their respective identities since in the case of known people, texting help to better convey emotions ensuring an atmosphere of ease. Furthermore, boys out won the girls in sending messages to unknown numbers.

This medium of communication gives a way to communication indirectly without having face to face interaction. Therefore, this kind of communication makes it easy for shy people to communicate with others. In rural or underdeveloped parts of the country, text messaging has become a most used method of communication due to many reasons like cheaper rates, convenience and privacy. Cellular companies offer highly affordable rates for text messaging. Even a person with very minimal income can afford these rates because of different sms packages. Hence, these tactics attract the subscribers and people are now using it frequently. Although, it doesn't mean teenagers don't like to make calls, it's just that they prefer text messaging more. Text messaging is an easy way to communicate when you're multitasking or in gatherings, where call is not feasible. This is why teenagers are more into text messaging and now it has become a life style for teenagers in Pakistan.

This study illustrates that most of the teenagers send 10-100 text messages a day. Though, respondents also revealed that most of them don't send text messages while studying because they lose focus. Text messaging has become a part of life style and text forwarding culture has been on rise. This trend of forwarding text messages has become a habit of teenagers mostly. Messages are shared further without even checking their appropriation. In case of religious messages, teenagers forward them overlooking their authenticity and true citations. Such practices intensify the texting behaviours and can pose challenging questions against the norms of communication. Therefore, it can be easily said that mobile phones are now essential part of teenager's lives. Apart from this, text messaging has opened a gateway for more convenient 
way of interaction. This technology is beneficial but it also raises questions about the negative impacts it has on young generations. In the nut shell, this technology is a mixed blessing with pros and cons both.

In this $21^{\text {st }}$ century, the communication process has become economical and easier. With each coming day diversified technologies are being innovated. Some people suggest that parental check is necessary for teenagers because in this age usage of mobile phones bring unrestricted autonomous freedom of communication which may bring unsolicited consequences.

\section{References}

AOL mobile (2002). Phone Flirts. AOL [On-line]. http://mobile.aol.co.uk/redesign/gallery/flirt/flirt0.jsp

Attaa, A. (2010). Pakistan Registers 98 Million Mobile Phone Users. http://propakistani.pk/2010/06/24/pakistan-registers-98-millionmobile-phone-users/

Bakke, E. (2010). A model and measure of mobile communication competence. Human Communication Research, 36, 348-371.

Bond, E. (2010). Managing mobile relationships: Children's perception of the impact of the mobile phone on relationships in their everyday lives. Childhood, 17, 514-529.

Campbell, S. W., \& Park, Y. J. (2008). Social implications of mobile telephony: The rise of personal communication society. Sociology Compass, 2, 371-387.

Cellular Subscribers Top 116.2 Million in Feb 2012. http://www.pta.com.pk

Chenault, B. G. (1998). Developing personal and emotional relationships via computermediated communication. CMC Magazine (On-Line), May

Choliz, M. (2010). Mobile phone addiction: Point of issue. Addiction, 105, 374. http://onlinelibrary.wiley.com/doi/10.1111/j.13600443.2006.01593.x/full

Danet, B. (1995). Playful expressivity and artfulness in computer-mediated communication. Computer-Mediated Communication (On-Line), 1.

Eva Lam, W. S.(2009). Multiliteracies on Instant Messaging in Negotiating Local, Translocal, and Transnational Affiliations: A Case of an Adolescent Immigrant. Reading Research Quarterly, 44 (4), 377-397.

Ezoe, S., Toda, M., Yoshimura, K., Naritomi, A., Den, R., \& Morimoto, K. (2009). Relationships of personality and lifestyle with mobile phone dependence among female nursing students. Social Behaviour and Personality, 37(2), 231-238.

Fortunati, L. (2002) The mobile phone: towards new categories and social relations, Information, Communication and Society, 5 (4), 513-528. https://doi.org/10.1080/13691180208538803

Geser, H. (2006). Pre-teen cell phone adoption: Consequences for later patterns of phone usage and involvement. Sociology in Switzerland: Sociology of the Mobile phone. http://socio.ch/mobile/t_geser2.pdf.

Horstmanshof, L., \& Power, M. R. (2005). Mobile phones, SMS, and relationships. Australian Journal of Communication, 32(1), 33-52.

Haig, M. (2002). Mobile marketing: The message revolution. London: Kogan Page Limited

Henderson, S., Taylor, R. and Thompson, R. (2002) In touch: young people, communication and technologies. Information, Communication and Society, 5(4), 494-512. https://doi.org/10.1080/13691180208538802 
Hofvenschiold, E. (2003). Determining Cultural Issues in Attitude to and Use of Mobile Phones, Proceedings of the German Chapter of Usability Professionals 2003, pp.171174

Horrey, W. J.,\&Wickens C. D. (2006). Examining the impact of cell phone conversations on driving using meta-analytic techniques. Human Factors, 48, 196-205.

Horst, H., Miller, D. (2005). From kinship to link-up: Cell phones and social networking in Jamaica. Current Anthropology, 46(5), 755-778. https://doi.org/10.1086/432650

Ito, M. (2006). Mobile Phones, Japanese Youth, and the Re-Placement of Social Contact: http://www.itofisher.com/mito/archives/mobileyouth.pdf

Ha, J. H., Chin, B., Park, D. H., Ryu, S. H., \& Yu, J. (2008). Characteristics of excessive cellular phone use in Korean adolescents. Cyber Psychology \& Behaviour, 11(6), 783 784. https://doi.org/10.1089/cpb.2008.0096

Jin, B., \& Peña, J. F. (2010). Mobile communication in romantic relationships: Mobile phone use, relational uncertainty, love, commitment, and attachment styles. Communication Reports 23, 1, 39-51.

Kasesniemi, E. L. \& Rautiainen, P. (2002). Mobile culture of children and teenagers in Finland. In J. E. Katz \& M. Aakhus (Eds.), Perpetual contact: Mobile communication, private talk and public performance (pp. 170-192). Cambridge: Cambridge University Press.

Katz, J. E. \& Aakhus, M. (2002). Perpetual contact: Mobile communication, private talk and public performance. Cambridge: Cambridge University Press

Kazi, A. M., Ali, M., Zubair, K., Kalimuddin, H., Kazi, A. N., Iqbal, S. P., ... \& Ali, S. A. (2018). Effect of mobile phone text message reminders on routine immunization uptake in Pakistan: randomized controlled trial. JMIR public health and surveillance, 4(1).

Kawasaki, N., Tanei, S., Ogata, F., Burapadaja, S., Loetkham, C., Nakamura, T. (2006). Survey on cellular phone usage on students in Thailand. Journal of Physiological Anthropology, 25, 377-382.

Lenhart, A. (2009). Teens and Mobile Phones Over the Past Five Years: Pew Internet Looks Back. Pew Internet \& American Life Project http://www.pewinternet.org/Reports/2009/14-Teens-and-Mobile-Phones-DataMemo.aspx August 2009.

Leung, L. (2001). College student motives for chatting on ICQ. New media \& society, 3(4), 483-500. https://doi.org/10.1177\%2F14614440122226209

Lee, J., Cho, B., Kim, Y., \& Noh, J. (2015). Smartphone addiction in university students and its implication for learning. In Emerging issues in smart learning (pp. 297-305). Springer, Berlin, Heidelberg. https://link.springer.com/chapter/10.1007/978-3-66244188-6_40

Lemola, S., Perkinson-Gloor, N., Brand, S., Dewald-Kaufmann, J. F., \& Grob, A. (2015). Adolescents' electronic media use at night, sleep disturbance, and depressive symptoms in the smartphone age. Journal of youth and adolescence, 44(2), 405-418. https://link.springer.com/article/10.1007\%2Fs10964-014-0176-X

Ling, R. \&Yttri, B. (2002). Hyper-co-ordination via mobile phones in Norway. In J.E. Katz \& M. Aakhus (Eds.), Perpetual contact: Mobile communication, private talk and public performance (pp. 139-169). Cambridge: Cambridge University Press

Lipscomb, T. J., Totten, J. W., Cook, R. A., \& Lesch, W. (2007). Cellular phone etiquette among college students. International Journal of Consumer Studies, 31,46-56.

Massimini, M., \& Peterson, M. (2009). Information and Communication Technology: Affects on U.S. college students. Cyberpsychology: Journal of Psychosocial Research on Cyberspace, 3(1). https://cyberpsychology.eu/article/view/4220 
Cellular Phone Text Messaging Patterns \& Teenagers of Southern Punjab ...

Matthews, R. (2004). The Psychosocial aspects of mobile phone use among adolescents. In Psych, 26(6), 16-19.

Nokia (2002). Are you ready for multimedia messaging service: an evolutionary approach to implementing MMS. Nokia [On-line]. www.nokia.com

Pakistan Ranks \#4 in SMS Usage (2009). http://jehanara.wordpress.com/2009/02/02/pakistanranks-4-in-sms-usage/.

Puro, J. (2002). Finland, a mobile culture. In J. E. Katz \& M. Aakhus (Eds.), Perpetual Contact: Mobile communication, private talk and public performance (pp. 18-29). Cambridge: Cambridge University.

Russell, L. (2010). The effects of text messaging on English grammar. EHow. Demand Media,3. Russell, L. (2010). http://www.ehow.com/list_5828172_effects-textmessaging-english-rammar.html

Stothart, C., Mitchum A., Yehnert C. (2015). The attentional cost of receiving a cell phone notification. J. Exp. Psychol. 41(4), 893-897. https://psycnet.apa.org/buy/2015-28923$\underline{001}$

Sutherland, J. (2002). "Cn u txt?" The Guardian. http://www.guardian.co.uk/print/0,3858,4543918-103680,00.html

Thurlow, C., \& Brown, A. (2003). Generation Txt? The sociolinguistics of young people's text-messaging. Discourse analysis online, 1(1), 30. Thurlow2003-DAOL.pdf 
Annexure

Annex-1: Text messaging Contraction trend being used in Pakistan

\begin{tabular}{|c|c|c|c|}
\hline Shortcut & Complete & Shortcut & Complete \\
\hline$?$ & I have a question & DNT & Don’t \\
\hline$?$ & What you mean? & DOOD & Dude \\
\hline$? 4 \mathrm{U}$ & Question for you & EI & Every one \\
\hline 121 & One to one & EFAT & Effort \\
\hline 143 & I love you & EOL & End of life \\
\hline 1432 & I love you too & $\mathrm{F} 2 \mathrm{~F}$ & Face to face \\
\hline 12AA41 & I for all \& all for one & FAQ & Frequently asked questions \\
\hline 182 & I hate you & $\mathrm{FB}$ & Facebook \\
\hline $10 \mathrm{X}$ & Thanks & GF & Girl friend \\
\hline 10Q & Thank you & G9 & Genius \\
\hline ICE & Once & GB & Good bye \\
\hline IDR & Wonder & GD & Good \\
\hline 2EZ & Too easy & GL & Good luck \\
\hline $2 \mathrm{MI}$ & Too much information & GNEI & Good night every one \\
\hline 2MOR & Tomorrow & GTG & Got to go \\
\hline 2NTE & Tonight & GS & Good short \\
\hline 4 & For & GUD & Good \\
\hline $4 \mathrm{AO}$ & For adults only & H8 & Hate \\
\hline 4NR & Foreigner & HAU & How are you \\
\hline $7 \mathrm{~K}$ & Sick & HAND & Have a nice day \\
\hline $\mathrm{ABT}$ & About & H-BDAY & Happy birthday \\
\hline $\mathrm{ABT} 2$ & About to & HRU & How are you \\
\hline ADR & Address & $\mathrm{HV}$ & Have \\
\hline APP & Application & HW & Homework \\
\hline $\mathrm{ARG}$ & Argument & 12 & I too (me too) \\
\hline ATB & All the best & IB & I am back \\
\hline ART & Are you there & $\mathrm{IC}$ & I see \\
\hline ARS & Are you serious & IDC & I don’t care \\
\hline B\& & Banned & IDK & I don't know \\
\hline B4 & Before & IIIO & Intel inside, idiot outside \\
\hline $\mathrm{BC}$ & Because & IK & I know \\
\hline $\mathrm{B} / \mathrm{C}$ & Because & ILY & I love you \\
\hline BCOS & Because & IMS & I am sorry \\
\hline B-DAY & birthday & IMU & I miss you \\
\hline $\mathrm{BF}$ & Boy friend & JOO & You \\
\hline $\mathrm{BF}$ & Best friend & JK & Just kidding \\
\hline BOL & Best of luck & $\mathrm{K}$ & Okay \\
\hline BRB & Be right back & KK & Okay okay \\
\hline CAM & Camera & KOOL & Cool \\
\hline $\mathrm{CM}$ & Call me & L8T & Later \\
\hline $\mathrm{CMON}$ & Come on & LOL & Laughing out loud \\
\hline $\operatorname{COS}$ & Because & M8 & Mate \\
\hline CRS & Create & MGMT & management \\
\hline $\mathrm{CU}$ & See you & $\mathrm{M}$ or $\mathrm{F}$ & Male or female \\
\hline CU2 & See you too & MU & Miss you \\
\hline CUL & See you later & NI & Nice one \\
\hline DNR & dinner & $\mathrm{NE}$ & Any \\
\hline NEI & Anyone & WRK & Work \\
\hline NOI & Number one & WU & What up \\
\hline NTHING & Nothing & XME & Excuse me \\
\hline NVR & Never & XLNT & Excellent \\
\hline NW & No way & $\mathrm{Y} ?$ & Why? \\
\hline $\mathrm{O} 4 \mathrm{U}$ & Only for you & $\mathrm{XF}$ & wife \\
\hline
\end{tabular}


Cellular Phone Text Messaging Patterns \& Teenagers of Southern Punjab ...

\begin{tabular}{|c|c|c|c|}
\hline OIC & Oh I see & YR & Your \\
\hline $\mathrm{OL}$ & Only joking & KM & Kilo meter \\
\hline OMG & Oh my God & V & We \\
\hline ONL & Online & 2MOROW & Tomorrow \\
\hline F9 & Fine & MINT & Minute \\
\hline PAT & Patrol & OR & Aur (and) \\
\hline PCM & Please call me & $\mathrm{K}$ & Kay \\
\hline PIC & Picture & $\mathrm{AOA}$ & Asslam-o-alaikum \\
\hline PL8 & Plate & WS & Wasalam \\
\hline PLS & Please & GR8 & Great \\
\hline PLZ & Please & SAD & :) \\
\hline PM & Private message & SMILE & ;) \\
\hline PPL & People & $\mathrm{NP}$ & No problem \\
\hline PZA & Pizza & GOVT & Government \\
\hline QIK & Quick & DR & Doctor \\
\hline $\mathrm{R}$ & Are & UNI & University \\
\hline R8 & Right & AFAIK & As for as I know \\
\hline RLY & Really & 2 & To \\
\hline RU & Are you? & 4 & For \\
\hline RUT & Are you there? & MSGNG & Messaging \\
\hline $\mathrm{S} 2 \mathrm{~S}$ & Sorry to say & Gal & Girl \\
\hline $\mathrm{SC}$ & Stay cool & QL & Cool \\
\hline SPK & Speak & ASL & Age sex location \\
\hline SQR & Square & BD & Baad \\
\hline SS & So sorry & НАНАНА & Laughing \\
\hline STR8 & Straight & HUH & What? \\
\hline SUP & What's up? & LV & Love \\
\hline $\mathrm{T}+$ & Think positive & OFC & Of course \\
\hline TBC & To be continued & PIX & Pictures \\
\hline TC & Take care & RPLY & Reply \\
\hline THX & Thanks & DLTE & Delete \\
\hline THANQ & Thank you & TRU & True \\
\hline UN4TUN8 & Unfortunate & $\mathrm{U} 2$ & You to \\
\hline UOK & Are you ok? & $\mathrm{VC}$ & Vice chancellor \\
\hline UR & Your & WRLD & World \\
\hline VRY & Very & WS & Wait \\
\hline W@ & What? & WRT & Write \\
\hline $\mathrm{W} / \mathrm{B}$ & Well come back & BIBI & Bye bye \\
\hline WAN2 & Want to & $\mathrm{R}$ u goin & Are you going? \\
\hline WC & Who cares & $\mathrm{BD}$ & Baad \\
\hline W/E & Whatever & G.9.8 & Good night \\
\hline WK & Week & NHI & Nahe \\
\hline $\mathrm{K}$ & Kay & AJ & Aaj \\
\hline ND & And & TMNY & Tum nay \\
\hline SB & Sub & GRP & Group \\
\hline Q & Kyun (Why) & I & Aik \\
\hline ME & Main & BTNG & Batting \\
\hline $\mathrm{HN}$ & Hun/hoon & BOWL & Bowling \\
\hline Cal & Call & YA & or \\
\hline
\end{tabular}

